\title{
Como ensinar higiene corporal para além das salas de aula? Relato de Experiência
}

\author{
Aline Vasconcellos Martins Vaz, Giulia Toledo Ferraz, Felipe Ribeiro Massardi, Sarah dos Santos \\ Clímaco, Yuri Pereira Martins, Larissa de Paula Rodrigues
}

\section{Resumo}

A educação em saúde é fundamental para a formação de indivíduos sujeitos de seu bem-estar, que assim, podem interferir para melhorar a qualidade de vida coletiva. Nesse sentido, considerando a escola como formadora dos hábitos humanos, observamos nesta um farto campo para o desenvolvimento da promoção da saúde. Fomentar o aprendizado em saúde no ambiente escolar, desenvolvendo uma atividade educativa sobre higiene corporal com crianças da educação infantil. Buscamos, com essa atividade, contribuir para a construção da percepção dessas crianças de que elas têm autonomia sobre sua saúde. Ademais, procuramos, também, trazer o conhecimento científico para o cotidiano de comunidades carentes. É relevante, ainda, nossa intenção de reduzir a incidência de patologias associadas às más condições de higiene. Realizamos a atividade com duas turmas de alunos do $4^{\circ}$ Ano da Escola Estadual José Lourenço de Freitas, no Bairro São José do Triunfo, em Viçosa - MG, e seus professores. Com base na noção de que sem vínculo não há aprendizado, ela transcorreu, primeiro, com uma conversa interativa com as crianças, onde foi possível captar sua realidade. Concomitantemente, introduzimos conhecimentos básicos sobre micro-organismos e suas relações com o cotidiano. Em seguida, apresentamos fotografias de patógenos, além de placas de Petri cultivadas com objetos, como moedas e saliva, mostrando-lhes a dimensão científica de sua saúde. Na sequência, ocorreu a parte instrutiva do evento, com explicações sobre lavagem de mãos e escovação dental. Ademais, considerando que crianças nessa fase ainda não tem sua capacidade de abstração consolidada, desenvolvemos duas brincadeiras para reforçar esse aprendizado. A primeira consistiu em um jogo de perguntas sobre hábitos de higiene, enquanto a segunda baseou-se em uma competição em que se estouravam balões com o nome de alimentos que deveriam ser classificados quanto aos seus efeitos na saúde bucal. No final, foram fixados cartazes com orientações nos banheiros e distribuídos panfletos. Os alunos receberam o evento de forma positiva, participando com entusiasmo das atividades. Com o empoderamento das crianças quanto à sua saúde, espera-se uma melhora de sua qualidade de vida, considerando as práticas de higiene assimiladas. Os ensinamentos despertaram nas crianças, ainda, o desejo pelo aprofundamento futuro no campo da saúde, fato interessante para o aumento de profissionais da área. Além disso, a partir do contato inicial com tais saberes, os alunos podem transformar-se em amplificadores dos hábitos aprendidos, uma vez que, pelo interesse demonstrado, provavelmente transmitirão a prática aos familiares. O presente trabalho ressaltou a importância da integração entre educação e saúde na promoção de bem estar. Ficou evidente, também que essa parceria deve ser formulada de forma interativa, visando à colaboração dos alunos, caminho ideal para que eles apliquem os ensinamentos no cotidiano. Por fim, desejamos que esse evento sirva de inspiração para mais atividades de educação em saúde, já que elas são potentes ferramentas de transformação social.

Descritores: Promoção da Saúde; Higiene Corporal; Educação Infantil 